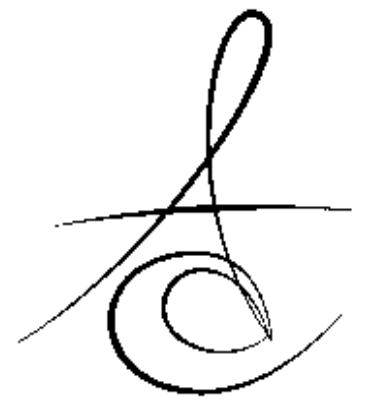

\title{
SABİT VE HAREKETLİ PROTEZÍN YENİDEN YAPIMI İLE ESTETİK VE FONKSİYONUN İYİLEŞTİRİLMESİ: OLGU SUNUMU
}

\section{IMPROVED OF ESTHET IC AND FUNCT ION W ITH REBU ILD ING OF F IXED AND REMOVABLE PART IAL DENTURES: CASE REPORT}

\author{
Yrd. Doç. Dr. Perihan OYAR*
}

Makale Kodu/Article code: 1071

Makale Gönderilme tarihi: 30.01.2013

Kabul Tarihi: 14.08.2013

\section{ÖZET}

Nanopartiküller nano boyutlarından dolayı fonksiyonellik, biyolojik özellikler, eşsiz fiziksel ve kimyasal özelliklerinin bir sonucu olarak büyük oranda dikkat çekmişlerdir. Metal esaslı nanomateryaller üstün özelliklerinden dolayı tüm bilim dallarında yeni bir ilgi alanı oluşturmuştur. Bunların uygulamaları yeni pratik ürünlerin gelişmesine yol açmıştır. Dolgu materyalleri, simanlar, fissür örtücüler, geçici restorasyonlar ve adezivler gibi antimikrobiyal etkiye sahip dental materyaller ortaya çıkmıştır. Metal nanopartiküller büyük yüzey alanı/hacim oranına sahip olduklarından dolayı iyi antimikrobiyal özellikler sergilerler. Bunlar çeşitli mikroorganizmaların büyüme inhibitörü olarak kullanılabilirler. Dahası, nanomateryallerin daha etkili olmaları biyomateryal ve tıp gibi farklı alanlarda kullanımlarını kolaylaştırmak için modifiye edilebilirler. Nanopartiküller ilaç salımı, çürük kontrolü ve remineralizasyon, biyofilm oluşumunun önlenmesi, periodontal enfeksiyon, kök kanal dezenfeksiyonu, dentin hassasiyetinin giderilmesi gibi diş hekimliğinin pek çok alanında kullanılmalarına rağmen bazı nanopartiküller oral ve diğer dokular için toksik olabilirler. İnsan hücreleri için nanoteknoloji ürünlerinin muhtemel toksisitesi ile ilgili bilgi sınırlıdır. Dental biyomateryaller üzerinde nanopartiküllerin uzun süreli antimikrobiyal, toksik, fiziksel ve klinik etkileri daha ileri çalışmalarda araştırılması gerekir.

Anahtar kelimeler: Nanoteknoloji, diş hekimliği, nanopartikül, anti-mikrobiyal ajan

\section{ABSTRACT}

Nano-structured materials have been receiving considerable attention as a results of their unique physical and chemical properties, biological properties, and functionality due to their nano-scale size. Metallicbased nano-structured materials have created a new interesting field in all sciences for continuous investigations due to their unique properties. Dental materials with antimicrobial activity such as filling materials, cements, sealants, materials for tem-porary restorations, and adhesives have emerged. Their applications have led to development of new practical productions. They show good antimicrobial properties due to their large surface area to volume ratios. They can be used as effective growth inhibitors of various microorganisms. Furthermore, nanomaterials can be modified of achieve better efficiency and to facilitate their applications in different fields such as biomaterials and medicine. Nanoparticles have been used in dentistry as drug-delivery, caries control and remineralization, management of dentinal hypersensivity, oral biofilm management, periodontal infection, root canal disinfection. However, certain nanoparticles may be toxic to oral and other tissues. The knowledge regarding the possible toxicity of nanotechnology products to human cell is limited. The long-term antibacterial, toxic, physical and clinical effects of nanoparticles on dental biomaterials should be investigated in future studies.

Key words: Nanotechnology, dentistry, nanoparticle, anti-infection agent.

\footnotetext{
*Hacettepe Üniversitesi Sağlık Hizmetleri Meslek Yüksek Okulu, Diş-Protez Teknolojisi,
} 


\section{GİRİş}

Nanopartiküller, prizma, çubuk, küp, küre, iğne şeklinde farklı morfolojilere sahip, yaklaşık olarak 5$100 \mathrm{~nm}$ boyutunda kolloidal yapılardır. Sentetik veya doğal kaynaklı bir makromolekülden meydana gelirler. ${ }^{1,2}$ Diş hekimliği ve tıp alanı dahil çeşitli alanlarda enfeksiyonla mücadele konusunda metal esaslı nanomateryaller yeni bir ilgi alanı oluşturmuşlardır. Nanopartiküllerin aktif yüzey alanı, kimyasal reaktiviteleri ve biyolojik etkileri mikrometre genişliğindeki partiküllerin aktif yüzey alanı, kimyasal reaktiviteleri, ve biyolojik etkilerine göre önemli derecede farklıdır. ${ }^{2,3}$ Metalik nanopartiküllerin bakteri, mantar vs. öldürme yeteneği, onların nano boyutlarından ve büyük yüzey-hacim oranına sahip ${ }^{2}$ olmalarından kaynaklandığı ileri sürülmüştür. ${ }^{4}$ Bu özellikleri mikrobiyal membranların birbirleriyle yakından etkileşimine izin verir. ${ }^{5}$ Metalik ve diğer nanopartiküller polimer esaslı dental materyaller ile kombine edilerek oral kavitede antimikrobiyal amaçla kullanılırlar. ${ }^{6}$

Bu derlemenin ana hedefi nanopartiküller ve bu partiküllerin diş hekimliğinde kullanım alanları hakkında bilgi vermektir. Bu amaçla yapılan literatür taramasında son yıllara ait literatürler öncelikli olmak üzere son yirmi yıla ait olan literatürler değerlendirmeye alınmıştır.

\section{Antimikrobiyal Nanopartikül Metaller}

Metaller uzun yıllardır antimikrobiyal ajan olarak kullanılmaktadırlar. Bakterilerin metal nanopartiküllerine karşı direnç kazanma ihtimali, diğer konvansiyonel ve dar spektrumlu antibiyotiklerden daha azdır. ${ }^{7}$

Gümüş $(\mathrm{Ag}+)$ iyonları dental ve biyomedikal uygulamalarda kullanılır.4,8 Ag nanopartiküllerinin, ya tek başına ya da diğer antimikrobiyal ajanlarla birlikte kullanımı iyi sonuçlar vermiştir.9,10 Doku şartlandırıcılar, akrilik rezinler ve ağız gargaralarında Ag zeolit kulanıIır. ${ }^{11-13}$ Özellikle hücre düzeyinde mikroorganizmalar ile olan ilişkisinde nanopartiküllerin nasıl davrandığı ile ilgili bilgi sınırlıdır ve Ag'ün antimikrobiyal etki mekanizması tam olarak anlaşılamamıştır. ${ }^{4}$ Çalışmalar Ag+ iyonlarının pozitif yüklenmesinin antimikrobiyal etki için önemli olduğunu göstermiştir. Pozitif yüklenmiş nanopartiküller ve negatif yüklenmiş bakterinin hücre membranı arasında elektrostatik çekim oluşur. ${ }^{14}$ Yapılan bir çalışmada bakteri membranının zarar görmesi ve yapısal değişikliklerin hücre ölümüne yol açtığı gösterilmiştir. ${ }^{9} \mathrm{Ag}$ nanopartikülleri ile temasa geçen bir bakteri hücresinin $\mathrm{Ag}+$ iyonlarını aldığı ve büyük olasılıkla $\mathrm{Ag}^{\prime}{ }^{\prime}$ ün resipratör enzimi inhibe ettiği ve böylece serbest radikallerin oluşmasını sağlayarak hücre membranına zarar verdiği ileri sürülmüştür. ${ }^{9} \mathrm{Ag}$ nanopartiküllerin şeklinin de antimikrobiyal aktivite üzerinde etkili olduğu gösterilmiştir. ${ }^{7}$

Bakır (Cu), Ag ile kıyaslandığında, antimikrobiyal özellikleriyle ilgili nispeten daha az araştırma raporu elde edilmiştir. Cu'ın Ag nanopartiküllerinin etkisine benzer etki gösterdiği ileri sürülür. Fakat, $\mathrm{Cu}$ nanopartiküllerinin mikroorganizmalara karşı sergilediği mekanizma tam olarak anlaşılamamıştır. Cu nanopartiküllerinin Ag nanopartiküllerine göre çok daha iyi antimikrobiyal etkiye sahip olduğunu gösteren çalışmaların yanı sıra, aksini gösteren çalışmalar ve her ikisinin birlikte kullanılması durumunda etkinin daha da arttığını gösteren çalışmalar vardır. ${ }^{15,16}$

Altın (Au), $\mathrm{Ag}$ ve $\mathrm{Cu}$ ile kıyaslandığında zayıf antimikrobiyal etki gösterir. ${ }^{17} \mathrm{Au}$ nanopartiküllerinin yaygın kullanımına rağmen bu partiküllerin mikroorganizmaları nasıl etkilediğine dair bilgi çok azdır. ${ }^{18}$

\section{Antimikrobiyal Nanopartikül Metal Oksitler}

Nanopartikül metal oksitler çok sayıda kenar, köşe ve diğer potansiyel reaktif bölgelere sahip alışılmamış kristal morfolojileri ve son derece yüksek yüzey alanları ile antimikrobiyal ajan olarak büyük ilgi görmüşlerdir, ${ }^{19}$ fakat toksik etkilerinden dolayı belirli metal oksitler halen inceleme aşamasındadırlar. ${ }^{20}$

Bakır oksitler ( $\mathrm{CuO}$ ve $\mathrm{Cu}_{2} \mathrm{O}$ ) monoklinik yapısı ile yarı iletken bir bileşimdir. Polarize edilmiş likit ve polimer ile (örneğin su) kolaylıkla karıştırılabilirler ve nispeten kimyasal ve fiziksel özellikler açısından stabildirler. Çünkü alışımamış kristal morfolojileri ve son derece yüksek yüzey alanlarına sahip olabilirler. ${ }^{19}$

Cinko oksit (ZnO) nanopartikül metaller ve metal oksitlerde olduğu gibi antimikrobiyal mekanizması tam olarak anlaşılamamıştır. Genellikle güvenilir ve biyouyumlu olarak kabul edilirler. ${ }^{19}$

Titanyum dioksit $\left(\mathrm{TiO}_{2}\right)$ fotokatalitik antimikrobiyal bileşik olarak yaygın kullanılmaktadır. Genellikle normalde kullanılan konsantrasyonlarda toksik olmadığı düşünülür, fakat son zamanlarda nano- $\mathrm{TiO}_{2}{ }^{\text {'in }}$ tehlikeli olabileceği düşüncesi vardır. ${ }^{21}$ 


\section{Nanopartikül Metal ve Metal Oksitlerin Oral Uygulamaları}

Aletler ve oral biyomateryallere fungal ve bakteriyel bağlanmayı azaltmak için Ag nanopartikülleri ile araştırmalar yapılmaktadır. ${ }^{4}$ Polimer materyallerinde kullanılan $\mathrm{Ag}$ nanopartiküllerinin miktarı polimerin fiziksel özellikleri üzerinde ters etkiye sebep olmaması açısından büyük öneme sahiptir. Ag ve titanyum nanopartikülleri dental kompozitlerde antibakteriyel özellik ve biyouyumluluğu artırmak için kullanılırlar. ${ }^{13,22,23}$ Nanopartiküller polisaj işleminden sonra düzgün bir yüzey elde edilmesini sağlar ve materyalin sertiğini ve aşınmaya karşı direncini artııılar. ${ }^{24-26} \mathrm{Ag}$ nanopartikülleri ortodontik tedavide dental braketlerin dişe bağlanmasında kullanılan adezivlere eklendiğinde antibakteriyel etki sergilerler. ${ }^{4,27} \mathrm{Ag}$ nanopartiküllerinin ilave edildiği adezivlerin konvansiyonel adezivlere göre daha kaba yüzeylere sahip olduğu ve bakteriyel adezyonun daha az olduğu gösterilmiştir. ${ }^{28}$ Biyofilm oluşumunun sekonder çürük oluşumuna sebep olabileceği bilinir ve rezin esaslı dental kompozitlerin başarısızlı̆ına sebep olur. Dental kompozite ilave edilmiş ZnO nanopartikülleri $S$. Sorbrinus biyofilm oluşumunu $10 \%$ dan daha az olmayan konsantrasyonlarda 3 günlük test süresinde önemli derecede inhibe ettiği görülmüştür. ${ }^{29} \quad \mathrm{Toz}^{\mathrm{TiO}_{2}}$ diş macunları içinde beyazlaştıııı olarak yaygın biçimde kullanııır. ${ }^{30}$ $\mathrm{TiO}_{2}$ nanopartikülleri cam ionomer simanlarda, ${ }^{31} \mathrm{Ag}$ nanopartikülleri dental rezin kompozitlerde, ${ }^{32} \mathrm{Ag}$ zeolite nanopartikülleri ise ağız gargaralarında ve diş macunlarında ${ }^{33}$ kullanılarak antimikrobiyal etki sağlanmıştır. Protez kaide materyalleri içinde Ag nanopartikülleri kullanılarak protez stomatitisini önlemek için potansiyel bir yaklaşım olabileceği ileri sürülmüştür. ${ }^{33,34}$ Sodager ve arkadaşları ${ }^{35}$ akrilik rezinler içinde kullanılan $\mathrm{TiO}_{2}$ ve $\mathrm{SiO}_{2}$ nanopartiküllerinin akrilik rezinin esneme dayanıkılığını ters etkileyebileceğini ve bunun direkt olarak nanopartiküllerin konsantrasyonuyla ilgili olduğunu belirtmişlerdir.

\section{Antiadeziv Nanopartiküller}

Chitosan nano-ve mikropartikülleri ilaç salımında kullanılabilen çok popüler bir materyaldir. ${ }^{36}$ Chitosan kabuklu hayvanların iskeletinde bulunan doğal bir biyopolimerdir ve lineer polisakkarin'dir. Katyonik, hidrofilik, nontoksik, biyouyumlu ve biyolojik olarak absorbe olabilir. Chitosan pozitif olarak yüklenir ve mukosal yüzeye bağlanmayı sağlayan asitte çözünebilir. Enterecoccus faecalisí öldürebilme yeteneğine sahip olan endodontik enfeksiyonların kök kanal dezenfeksiyonunda kullanılırlar. ${ }^{37}$ Kishen ve arkadaşlar ${ }^{38}$ $\mathrm{ZnO}$ ve chitosan nanopartiküllerinin kombinasyonunun ve yalnızca ZnO'in önemli derecede Enterecoccus faecalis'nin dentine tutulumunu önemli derecede azalttığını göstermişlerdir.

Silika ve silika nanopartikülleri diş macunlarının içinde uzun yıllardır kullanılır. Biyofilm esaslı mikrobiyal hücreleri öldürmek için silika nanopartikülleri ile nitrik oksit kullanıımıştır. Nitrik oksitin hızlı difüzyonu, biyofilm matriksi içine penetrasyonu artırabilir ve böylece bakteri içeren biyofilme karşı etkiyi artıırı. ${ }^{39}$

$\mathrm{SiO}_{2}-\mathrm{Na}_{2} \mathrm{O}-\mathrm{CaO}-\mathrm{P}_{2} \mathrm{O}_{5}$ sisteminin biyoaktif camlarının antimikrobiyal etkiye sahip olduğu gösterilmiştir ve dentin dezenfektanı olarak kalsiyum hidroksite alternatif olabilmesi konusunda çalışılmalar devam etmektedir. 20-60 nm boyutu ile amorf nanopartikül formundadırlar ve camın aktif yüzey değişimi ve cam partikül boyutunun azalmasından dolayı (10 kattan daha fazla olarak) mikron boyutlu materyallere göre üstün olabilir ve artmış antimikrobiyal etkiyi ve supsansiyon içine iyonik salınımı önemli derecede arttııılar. ${ }^{40}$

Hidroksiapatit (HA) partiküllerinin remineralizasyonu sağlaması ve oral biyofilm oluşumu üzerinde etkili olduğu gösterilmiştir. ${ }^{41}$ Oral bakım ürünlerinde nanoboyutlu apatit partikülleri kulanımaktadır. ${ }^{42}$

\section{Nanopartikül Metal ve Nanopartikül Metal Oksitlerde Toksisite}

İnsan için nanoteknoloji ürünlerinin muhtemel toksisitesi ile ilgili bilgi sınırlıdır. ${ }^{43}$ Nanoteknolojinin güvenli kullanımı biyolojik sistemler ve bu materyaller arasındaki etkileşimi anlamayı gerektirir. ${ }^{44}$ Nanopartikülün biyouyumlu olup olmadığını tespit etmek için ilk önce sitotoksisitesinin tespit edilmesi gerekir. ${ }^{45}$ Çoğunlukla nanopartiküllerin toksisitelerinin belirlenmesinde nanopartiküllerin boyutları önemli rol oynar. Çünkü nanopartiküller o kadar küçüktür ki onlar hücre membranına penetre olabilirler ${ }^{69}$ ve hücre içi komponentler ile toksik reaksiyonlara neden olabilirler. ${ }^{46}$ Nanopartiküllerin konsantrasyonu da toksisitede önemlidir. Yüksek konsantrasyonlardaki nanopartiküller düşük konsantrasyonlardaki nanopartiküllere göre hücre için daha toksik olabilirler. Nanopartiküllerin hücreler ile olan yüzey etkileşimleri de toksik etkiye sebep olabilir. ${ }^{46}$

$\mathrm{ZnO}$ genellikle güvenilir ve biyouyumlu olarak 
kabul edilir. ${ }^{19}$ Çalışmalar göstermiştir ki, ZnO gibi bazı nano boyutlu metal oksitler seçici toksik etkiye sahiptirler. ${ }^{47,48} \quad \mathrm{TiO}_{2}$ 'in normalde kullanılan konsantrasyonlarda toksik olmadığı düşünülür, fakat son zamanlarda nano- $\mathrm{TiO}_{2}$ 'in tehlikeli olabileceği düşüncesi vardır. ${ }^{21}$ Karlsson ve arkadaşları ${ }^{20}$ metal oksit nanopartiküllerinin $40 \mu \mathrm{g} / \mathrm{mL}$ den daha düşük konsantrasyondaki partiküllerden daha toksik olduğunu bulmuşlardır. CuO'in toksik olduğu, güneş kremleri ve kozmetiklerin içinde bulunan $\mathrm{ZnO}$ ve $\mathrm{TiO}_{2}$ nanopartküllerinin önemli derecede sitotoksik olduğu ve DNA' ya zarar verici etkileri olduğu görülmüştür. Katyonik partiküller veya yüksek yüzey reaktivitesine sahip partiküller çok daha toksik olabilirler. Daha hidrofobik ve daha zayıf dağılan partiküller retiküloendotelyal sistemce hızlı biçimle uzaklaştırılır, bunların daha toksik olduğu görülür. ${ }^{49} \mathrm{Bir}$ nanopartikül formunda Cu'ın aktif olarak vücuttan salındığı bilinirken, partikül formunda olmayan Ag vücut içinde birikebilir, fakat nanopartikül formunda bu metallerce zehirlenme tehlikesi çok açık değildir. ${ }^{43}$

Antimikrobiyal etki ve nanopartiküllerin boyutu arasında ters ilişki vardır. ${ }^{4}$ Daha küçük $\mathrm{Ag}$ nanopartikülleri daha büyük olanlardan daha fazla okside olduğundan dolayı çok daha toksiktir. ${ }^{50}$

\section{Karbon Nanotüp Esaslı Materyaller}

Doku, organ ve hücreler nanofibröz kollojen fibrillerden oluşan nano yapıdaki ekstrasellüler matriks ile etkileşimdedirler ve bu hücrelerin birbirleriyle ve çevresiyle çoklu etkileşimleri iyileşmeyi etkilemektedir. ${ }^{51}$ Nanomateryaller bazı özelliklerde doğal ekstrasellüler matrikse benzerler ve eşsiz fizikokimyasal özelliklere sahiptirler ve yönlendirilmiş doku rejenerasyonu kadar hücre büyümesini stimüle edebilirler. Karbon nanotüpler (CNTs) aslında karbon atomlarından oluşan silindirik moleküllerdir. ${ }^{52}$ CNTSs tek ya da çok tabaka içinde katlanmış grafitin hekzagonal tabakalarıdır. ${ }^{53}$ CNT $1 \mathrm{~nm}$ e kadar küçük çap ve birkaç mikrometre uzunluğa sahiptir. Diğer bir yandan, karbon nanofiberler (CNFs) çok uzundur, yaklaşık 10-1000 nm çapındadırlar. Tek grafen (saf karbonun ince tabakası) tabakadan oluşan tek duvarlı (single-walled) karbon nanopartiküllerini (SWCNT) oluştururken, birkaç grafen tabaka çok duvarlı (multi-walled) karbon nanopartiküllerini (MWCNTs) oluşturur. ${ }^{54}$ CNTs karbon bağının spesifik özelliğinden kaynaklanan eşsiz mekanik, termal, ve elektriksel özelliklere sahiptir. ${ }^{55}$ Nanotüpler metalik ve yarı iletken olabilirler. CNT'nin elektrik iletkenliği pek çok biyolojik uygulamalarda avantaj olabilir. ${ }^{22}$ SWCNTs ortalama $1,5 \mathrm{~nm}$ çapına sahiptir. Aksine MWCNTs' nin çapları tipik olarak 10-100 nm arasında değişir. Bunların kemik doku mühendisliği için iyi bir aday olduğu belirtilmektedir. ${ }^{56}$ Çalışmalar CNTs/ (CNFs)'nin osteokonduktif olmalarından dolayı kemik rejenerasyonu için çok iyi olduğunu göstermiştir. ${ }^{57}$ CNTs/CNFs ve hücreler arasındaki elektrokimyasal etkileşimden dolayı böyle bir mekanizmanın olabileceği ifade edilir. CNTs/CNFs kemik doku mühendisliğinde iki alanda kullanııı: elektrik iletkenliğinin artışı ve titanyum implant yüzeylerinin biyoaktivitesini artırmak için yüzey kaplanmasında kullanııır. ${ }^{58}$

\section{Karbon Nano Tüplerin Oral Uygulamaları}

Diş hekimliğinde karbon nanomateryal uygulamalarının bir kullanım alanı dentine yakın elastikiyet modülüs sahip oldukları için karbon-fiber ile kuvvetlendirilmiş epoksi rezin postlardır, ve bunlar aşınmazlar, geleneksel metal döküm post işlemlerinden daha kısa sürede yapılırlar, daha ucuz klinik işlemler gerektirirler. ${ }^{59}$ Diğer bir uygulama alanı mekanik gereksinimleri karşılamak için karbon/grafit fiberle güçlendirilmiş poli (metil metakrilat) (PMMA) protez kaidesidir. ${ }^{60}$ Fakat, karbon materyalleriyle ilgili önemli bir problem klinik uygulamalarda bunların siyah renklerinden dolayı estetik zayıflıklarıdır. Kobayashi ve arkadaşları ${ }^{61} \mathrm{HA}^{\prime} \mathrm{i}$ kompozitler için kuvvetlendirici olarak kullanmışlardır ve $\mathrm{CNF} / \mathrm{HA}$ için kırılma tokluğu değerleri HA için elde edilenlerinkinden 1,6 kez daha fazla olduğunu bulmuşlardır.

Kompozit rezin ve dentin ara yüzeyinde $\mathrm{CNT}^{\prime}$ lerin varlığı çürüğe karşı koruma sağlayarak sekonder çürük oluşum şansını azaltabilir, fakat, CNT'den dolayı dentin-kompozit ara yüzeyinde gri renkleşme oluşur. İşlevsel hale getirilmiş SWCNT daha fazla stresi önemli oranda absorbe ederek bükülme dayanıklılı̆ını artırmışır, ${ }^{62}$ fakat CNT ile kuvvetlendirilmiş kompozit rezinin kullanılabilirliliği CNT'nin siyah renginden dolayı engellenmiştir.

PMMA çiğneme kuvvetleri altında kııı̆a hassastır ve düşük kırılma dayanıklığına sahiptir. Protez kaidesinin bükülme dayanıklığı ve kırıma tokluğunu artırmak için PMMA'ın içine MWCNT'ün katııması doza bağlı olarak polimerin bükülme dayanıklıı̆ı ve yorulma performansını artırmışır. MWCNT'ün çatlak oluşumundan önce PMMA matriksini kuvvetlendirebildiği ve kırı̆ı̆n ilerlemesini durdurduğu tahmin edilmiştir. 
Mekanik özellikleri önemli oranda artmış olsa da CNT uygulamalarının bir dezavantajı protez kaidesinin siyah renkli olmasıdır.63

Nanopartiküller kolayca kümelenme ve toplanma eğilimi gösterdikleri için polimer matriks üzerinde kuvvetlendirici etkiyi azaltıllar ve zayıf dağıımları materyalin özelliklerinin zayıflamasına yol açar. ${ }^{64} \mathrm{Kemik}$ defektlerinin tedavisi amacıly fibroblastlara adezyonu sağlayarak MWCNT yüzeyi üzerine apatit kristal oluşu$\mathrm{mu}$ ve osteoblast proliferasyonu sağlayabilen yeni bir chitosan-MWCNT bileşimi geliştirilmiştir. ${ }^{65}$ CNT'ün ilave avantajı iletkenlik özelliği ile nöral stimülasyon ve kemik iyileşmesine yardım eder. ${ }^{66,67}$ CNTs'nin proteine tutunma yeteneğinin keşfedilmiş olması bunların protein veya gen için bir taşıyıcı görevi yapabileceğini göstermiştir. 68,69 İşlevsel hale getirilmiş CNT bazı hücreler içine penetre olabilirler, bu özelliklerinden dolayı protein, gen ve ilaç salımı amacıyla kulanılabilirler. ${ }^{70}$ Diş hekimliğinde implant uygulamaları için, CNTs titanyum implantların yüzeyini kaplamada kullanılabilirler. ${ }^{71}$ Diş hekimliğinde CNTs/CNFs'in diğer bir muhtemel uygulama alanı kırıma tokluğunu artırmak için CNT/CNF ile güçlendirilmiş seramiklerde kullanılmasıdır. Üstün mekanik özellikler ve mükemmel kimyasal stabilitelerinden dolayı CNTs'in küçük miktarlarının seramik materyaller ile birlikte üretilmesi konusundaki araştırmalar devam etmektedir. ${ }^{72}$

\section{Karbon Nanomateryallerin Sitotoksisitesi}

Bir materyalin vücuda girdiği zaman yabancı madde cevabı verip vermeyeceğini anlamak çok önemlidir. CNTs ve CNFs'in sitotoksisitesi ile ilgili literatürde pek çok tartışma vardır. ${ }^{73}$ Bazı çalışmalar CNTs'in memeli hücreleri için toksik olduğunu rapor etmişken ${ }^{74,75}$ diğerleri biyouyumlu olduğunu ileri sürmüşlerdir. ${ }^{76,77}$ Hücre kültürü içinde dağılmış CNTs/CNFs ile yapılan çalışmalar düşük biyouyumluluk göstermişken, diğer çalışmalar CNT/CNF yüzeyi üzerinde osteoblast ve nöronların hücre büyümesini göstermiştir. ${ }^{57,78}$ CNTs'i saflaştırmak için pek çok teknik kullanılmaktadır. Bunlar asit uygulama, ${ }^{79}$ termal oksidasyon, ve organik çözücü kullanarak ultrasonikasyon ve santrifüjlemenin kombinasyonudur. ${ }^{80}$ MWCNT, karbon grafit, aktif karbon ile kıyaslandığında saflaştııımış SWCNTs geniş yüzey alanlarından dolayı hücresel davranış üzerinde en fazla ters etkiye sahip olmuştur. ${ }^{74}$ Asit uygula- masıyla oluşturulmuş SWCNT yüzeyinde fonksiyonel grup (carboxyl ve hydoxyl) yoğunluğundan dolayı, saflaştırımış
SWCNTs, modifiye edilmemiş SWCNTs'den çok daha sitotoksiktir. ${ }^{81}$

CNTs/CNFs'de toksisitesinin birinci kaynağı kobalt, nikel gibi katalizör metal artıklarından gelir. ${ }^{82}$ Eğer saf ürünler kullanilırsa bu metallerin biyolojik sistemler için toksik olduğu bilinir. Bu dezavantaj çözünürlük ve biyolojik özellikleri artırmak için kimyasal olarak modifiye edilmiş biyomedikal uygulama için kullanılan çoğu CNTs/CNFs'de metal iyonlarının oksidatif işlem ile uzaklaştııı ıması işlemi ile elimine edilmiştir. ${ }^{83}$ Kimyasal olarak işlevsel hale getirilmiş CNTs' in nöron ve osteoblast gibi farklı hücre tipleri üzerinde biyouyumlu olduğu görülmüştür. ${ }^{57} \mathrm{CNTs} / \mathrm{CNFs}^{\prime}$ de toksisitesinin ikinci kaynağı bunların iğne şekilli, uzun fibröz yapılarından kaynaklanabileceğidir. ${ }^{84}$ Böyle bir görüşe göre CNTs/CNFs'in daha kısa ve küçük yapılması bunları daha az toksik yapar.

CNTs'in toksisitesi ile ilgili sonuçların farklı̆ı̆ı; kullanılan teknikler, hücre tipleri, işlevsel hale getirilme oranı, yabancı maddenin varlığına dayanır. Nanotüplerin toksisitesi için en az 2 ya da daha çok bağımsız testin kullanılması önerilmiş̧ir. ${ }^{85}$ Nanotüplerin medikal uygulamada yaygın olarak kabul edilmesinden önce, uzun süreli toksisitesinin değerlendirilmesi gerekmektedir.

\section{SONUÇ}

Nanopartiküller sahip oldukları üstün özelliklerden dolayı yaygın kullanım alanına sahiptirler ve sahip oldukları avantajlardan dolayı son yıllarda yoğun olarak araştırımaktadırlar. Dental biyomateryaller üzerinde nanopartiküllerin uzun süreli antimikrobiyal, toxic, fiziksel ve klinik etkileri daha ileri çalışmalarda araştırıması gereken bir konudur. Gelecekteki keşifler muhtemelen bu nanopartiküllerin antimikrobiyal etkilerinin maksimum düzeyde, toksisitelerinin ise minimal düzeyde olması yönünde olacaktır. Nanoteknoloji, materyal biliminin gelişmesiyle diş hekimliği ve oral teşhis ve tedavi metodlarıla ilgili alanlarda ilerleme sağlayarak pek çok yeni gelişmeye izin verecektir.

\section{KAYNAKLAR}

1. Cushing BL, Kolesnichenko VL, O'Connor $\mathrm{CJ}$. Recent advances in the liquid-phase syntheses of inorganic nanoparticles. Chem Rev 2004; 104: 3893-3946. 
2. Kavaz D. Nanoteknoloji. Nanobülten 2011; 13: 129.

3. Allaker RP, Ren GG. Potential impact of nanotechnology on the control of infectious diseases. Trans R Soc Trop Med Hyg 2008; 102: 12.

4. Melo MA, Guedes SF, $\mathrm{Xu} H \mathrm{H}$, Rodrigues LK. Nanotechnology-based restoative materials for dental caries management. Trends Biotechnol 2013; 31: 459-67.

5. Morones JR, Elechiguerra JL, Camacho A, Holt K, Kouri JB, Ramirez JT. The bactericidal effect of silver nanoparticles. Nanotechnology 2005; 16: 2346-53.

6. Monteiro DR, Gorup LF, Takamiya AS, RuvolloFilho AC, Camargo ERde, Barbosa DB. The growing importance of materials that prevent microbial adhesion: antimicrobial effect of medical devices containing silver. Int J Antimicrob Agents 2009; 34: 103-10.

7. Pal S, Tak YK, Song JM. Does the antibacterial activity of silver nanoparticles depend on the shape of the nanoparticle? A study of the Gramnegative bacterium Escherichia coli. Appl Environ Microbiol 2007; 73: 1712-20.

8. Herrera M, Carrion P, Baca P, Liebana J, Castillo A. In vitro antibacterial activity of glass-ionomer cements. Microbios 2001; 104: 141-8.

9. Sondi I, Salopek-Sondi B. Silver nanoparticles as an antimicrobial agent: a case study on E. coli as a model for Gram-negative bacteria. J Colloid Interface Sci 2004; 275: 177-82.

10. Rai M, Yadav A, Gade A. Silver nanoparticles as a new generation of antimicrobials. Biotechnol Adv 2009; 27: 76-83.

11. Casemiro LA, Gomes-Martins CH, Pires-de-Souza Fde C, Panzeri H. Antimicrobial and mechanical properties of acrylic rezins with in corporated silver-zinczeolite-Part1. Gerodontology 2008; 25: 187-94.

12. Kawahara K, Tsuruda K, Morishita M, Uchida M. Antibacterial effect of silver-zeolite on oral bacteria under an aerobic conditions. Dent Mater 2000; 16: 452-5.

13. Homouda MI. Current perspectives of nanoparticles in medical and dental biomaterials. J Biomed Res 2012; 26: 143-51.
14. Kim JS, Kuk E, Yu KN, Kim JH, Park SJ, Lee $\mathrm{HJ}$, Kim SH, Park YK, Hwang CY, Lee YS, Jeong DH, Cho MH. Antimicrobial effects of silver nanoparticles. Nanomedicine 2007; 3: 95-101.

15. Yoon KY, Hoon Byeon J, Park JH, Hwang J. Susceptibility constants of Escherichia coli and Bacillus subtilis to silver and copper nanoparticles. Sci Tot Environ 2007; 3 73: 572-5.

16. Ren G, Hu D, Cheng EWC, Vargas-Reus MA, Reip $P$, Allaker RP. Characterisation of copper oxide nanoparticles for antimicrobial applications. Int J Antimicrob Agents 2009; 33: 587-90.

17. Lin CC, Yeh YC, Yang CY, Chen CI, Chen GF, Chen CC, Wu YC. Selective binding of mannose encapsulated gold nanoparticles to type I pili in Escherichia coli, J Am Chem Soc 2002; 13: 155168.

18. Williams DN, Ehrman SH, Pulliman Holoman TR. Evaluation of the microbial growth response to inorganic nanoparticles. J Nanobiotech 2006; 28; 4: 3.

19. Stoimenov PK, Klinger RL, Marchin GL, Klabunde $\mathrm{KJ}$. Metal oxide nanoparticles as bactericidal agents. Langmuir 2002; 18: 6679-86.

20. Karlsson HL, Cronholm P, Gustafsson J, Moller L. Copper oxide nanoparticles are highly toxic: a comparison between metal oxide nanoparticles and karbon nanotubes. Chem. Res Toxicol 2008; 172632.

21. Blake DM, Maness PC, Huang Z, Wolfrum EJ, Jacoby WA, Huang J. Application of the photocatalytic chemistry of titanium dioxide to disinfection and the killing of cancer cells. Sep Purif Methods 1999; 28: 1-50.

22. Mantri SS, Mantri SP. The nano era in dentistry. J Nat Sci Biol Med 2013; 4: 39-44.

23. Bayram C. İmplant teknolojisine nano yaklaşımlar. Nanobülten 2011; 13: 8-11.

24. Türkün ŞL, Uzer Çelik E. Antibakteriyel adeziv ile uygulanan kompomer ve nanofil kompozit restorasyonların bir yıllık klinik performansı. G Ü Diş Hek Fak Derg 2007; 24: 1-8.

25. Gökay N, Türkün LŞ. Farklı kompozit rezin materyallerin aşınma ve sertlik özelliklerin karşılaştırmalı olarak incelenmesi. A Ü Diş Hek Fak Derg 2002; 28: 263-70. 
26. Ulusoy N, Gökay O, Müjdeci A. Farklı kalınlıklarda uygulanan yeni geliştirilmiş üç kompozitin yüzey sertliği. A Ü Diş Hek Fak Derg 2000; 27: 29-35.

27. Borzabadi A, Borzabadi E, Edward L. Nanoparticles in orthodontics, a review of antimicrobial and anticarries applications. Acta Odontol Scand 2013; 10 (basımda).

28. Ahn SJ, Lee SJ, Kook JK, Lim BS. Experimental antimicrobial orthodontic adhesives using nanofillers and silver nanoparticles. Dent Mater 2009; 25: 206-13.

29. Aydin Sevnic B, Hanley L. Antibacterial activity of dental composites containing zinc oxide nanoparticles. J Biomed Mater Res B Appl Biomater 2010; 94; 22-31.

30. Giersten E. Effects of mouth rinses with triclosan, zincions, copolymer, and sodium lauryl sulphate combined with fluoride on acid formation by dental plaque in vivo. Caries Res 2004; 38: 430-5.

31. Stephen KW, Dentrifices: recent clinical findings and implications for use. Int Dent J 1993; 43: 54953.

32. Ahn S, Lee S, Kook J, Lim B. Experimental antimicro-bial orthodontic adhesives using nanofillers and silver nanoparticles. Dent Mater 2009; 25: 206-13.

33. Boldyryeva H, Umeda N, Plaskin OA, Takeda Y, Kishi-moto N. Highfluence implantation of negative metal ions into polymers for surface modification and nanoparticle formation. Surf Coat Tech 2005; 196: 373-7.

34. Mariatti M, Azizan A, See $\mathrm{CH}$, Chong KF. Effect of silane-based coupling agent on the properties of sil-ver nanoparticles filled epoxy composites. Compos Sci Technol 2007; 67: 2584-91.

35. Sodager A, Bahador A, Khalil S, Shahroudi As, Kassaee MZ. The effect of $\mathrm{TiO}_{2}$ and $\mathrm{SiO}_{2}$ nanoparticles on flexural strength of poly (methyl methacrylate) acrylic resins. J Prosthodont Res 2013; 57: 15-9.

36. Kumar M, Muzzarelli RAA, Muzzarelli C, Sashiwa $H$, Domb AJ. Chitosan chemistry and pharmaceutical perspectives. Chem Rev 2004; 104: 6017-84.

37. Lin LM, Skribner JE, Gaengler P. Factors associated with endodontic failures. J Endod 1992; 18: 625-7.
38. Kishen A, Shi Z, Shrestha A, Neoh KG. An investigation on the antibacterial and antibiofilm efficacy of cationic nanoparticulates for root canal infection. J Endod 2008; 34: 1515-20.

39. Hetrick EM, Shin JH, Paul HS, Schoenfisch MH. Anti-biofilm efficacy of nitric oxide-releasing silica nanoparticles. Biomaterials 2009; 30: 2782-9.

40. Waltimo T, Brunner TJ, Vollenweider M, Stark WJ, Zehnder M. Antimicrobial effect of nanometric bioactive glass 45S5. J Dent Res 2007; 86: 754-7.

41. Venegas SC, Palacios JM, Apella MC, Morando PJ, Blesa MA. Calcium modulate sinter actions between bacteria and hydroxyapatite. J Dent Res 2006; 85: 1124-8.

42. Rahiotis C, Vougiouklakis G, Eliades G. Characterization of oral films formed in the presence of a CPP-ACP agent: an in situ study. J Dent 2008; 36: 272-80.

43. Seetharam RN, Sridhar KR. Nanotoxicity: threat posed by nanoparticles. Curr Sci 2006; 93: 769-70.

44. Pankhurst QA, Connolly J, Jones SK, Dobson J. Applications of magnetic nanoparticles in biomedicine. J Phys D Appl Phys 2003; 36: 16781.

45. Stewart PS. Diffusion in biofilms. J Bacteriol 2003; 185: 1485-91.

46. Shukla R, Bansal V, Chaudhary M, Basu A, Bhonde RR, Sastry $M$. Biocompatibility of gold nanoparticles and their Endocytotic Fate inside the cellular compartment: a microscopic overview. Langmuir 2005; 21: 10644-54.

47. Reddy KM, Feris K, Bell J, Wingett DG, Hanley C, Punnoose A. Selective toxicity of zincoxide nanoparticles to prokaryotic and eukaryotic systems. Appl Phys Lett 2007; 90: 902.

48. Zhang LL, Jiang YH, Ding YL, Povey M, York D. Investigation in to the antibacterial behaviour of suspensions of $\mathrm{ZnO}$ nanoparticles ( $\mathrm{nnO}$ nanofluids). J. Nanopart Res 2007; 9: 479-89.

49. Nel AE, Mädler L, Velegol D, Xia T, Hoek EM, Somasundaran P. Klaessig F, Castranova V, Thompson M. Understanding biophysicochemical interactions at the nano-biointerface. Nat Mater 2009; 8: 543-57.

50. Lok CN, Ho CM, Chen R, He QY, Yu WY, Sun H, Tam PK, Chiu JF, Che CM. Silver nanoparticles: partial oxidation and antibacterial activities. J Biol Inorg Chem 2007; 12: 527-34.

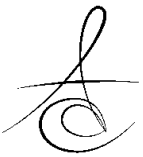


51. Lütfioğlu M. Periodontal rejenerasyon ve büyüme faktörleri. Atatürk Üniv. Diş Hek Fak Derg 2007; 17: 35-43.

52. Zhang L, Webster TJ. Nanotechnology and nanomaterials: promises for improved tissue regeneration. Nano Today 2009; 4: 66-80.

53. Collins PG, Avouris P. Nanotubes for electronics. Sci Am 2000; 283: 62-9.

54. Tran PA, Zhang $\sqcup$, Webster TJ. Carbon nanofibers and carbon nanotubes in regenerative medicine. Adv Drug Deliv Rev 2009; 61: 1097-114.

55. Martins-Jûnior PA, Alcântara CE, Resende RR, Ferreina AS. Carbon nanotubes and perspectives in oral regenerative medicine. J Dent Res 2013; 92: 575-83.

56. Lin Y, Taylor S, Li H, Fernando KAS, Qu L, Wang W, Lingrong G, Zhou B, Sun YP. Advances toward bioapplications of carbon nanotubes. J Mater Chem 2004; 14: 527-41.

57. Zanello LP, Zhao B, Hu H, Haddon RC. Bone cell proliferation on carbon nanotubes. Nano Lett 2006; 6: 562-7.

58. Webster TJ, Waid MC, McKenzie JL, Price RL, Ejiofor JU. Nano-biotechnology: carbon nanofibres as improved neural and orthopaedic implants. Nanotechnology 2004; 15: 48-54.

59. Fredriksson M, Astba“ck J, Pamenius M, Arvidson K. A retrospective study of 236 patients with teeth restored by carbonfiber-reinforced epoxy rezin posts. J Prosthet Dent 1998; 80: 151-7.

60. Larson WR, Dixon DL. Aquilino SA, Clancy JM. The effect of carbon graphite fiber reinforcement on the strength of provisional crown and fixed partial denture rezins. J Prosthet Dent 1991; 66: 816-20.

61. Kobayashi S, Kawai W. Development of carbon nanofiber reinforced hydroxyapatite with enhanced mechanical properties. Compos Part A 2007; 38: 114-23.

62. Zhang F, Xia Y, Xu L, Gu N. Surface modification and microstructure of single-walled carbon nanotubes for dental rezin-based composites. ] Biomed Res B Appl Biomater 2008; 86: 90-7.

63. Meng T, Latta M. Physical properties of four acrylic denture base rezins. J Contemp Dent Practise 2005; 16: 93-100.

64. Kumar PS, Kumar S, Savadi RC, John J. Nanodentistry: A Paradigm Shift-from Fiction to Reality. J Indian Prosthodont Soc 2011; 11: 1-6
65. Yang J, Yao Z, Tang C, Darwell BW, Zhang H, Pan L, Liu J, Chen Z. Growth of apatite on chitosan multiwall carbon nanotube composite membranes. Appl Surf Sci 2009; 255: 8551-5.

66. Lovat V, Pantarotto D, Lagostena L, Cacciari B, Grandolfo M, Righi M, Spalluto G, Prato M, Ballerini L. Carbon nanotube substrates boost neuronal electronic signalling. Nano Lett 2005; 5: 1107-10.

67. Yılmaz N, Akaya M. Nanoteknoloji. Türk Diş Hekimleri Birliği Dergisi 2007; 101: 76-80.

68. Cui D. Advances and prospects on biomolecules functionalized carbon nanotubes. J. Nanosci Nanotechnol 2007; 7: 1298-314.

69. Derman S, Kızılbey K, Akdetse ZM. Polymeric nanoparticles. Mühendislik ve Fen bilimleri Dergisi 2013; 31; 109-22.

70. Li X, Fan Y, Watari F. Current investigations into carbon nanotubes for biomedical application. Biomed Mater 2010; 5: 022001.

71. Zeng HT, Lacefield WF. XPS, EDX and FTIR analysis of pulsed laser deposited calcium phosphate bioceramic coatings: the effects of various process parameters. Biomaterials 2000; 21: 23-30.

72. Chen Y, Zhang TH, Gan CH, Yu G. Wear studies of hydroxyapatite composite coating reinforced by carbon nanotubes. Carbon 2007; 45: 998-1004.

73. Suh WH, Suslick KS, Stucky GD, Suh YH. Nanotechnology, nanotoxicology and neuroscienc. Prog Neurobiol 2008; 87: 133-70.

74. Tian F, Cui D, Schwarz H, Estrada GG, Kobayashi $\mathrm{H}$. Cytotoxicity of single-walled carbon nanotubes on human fibroblasts. Toxicol In Vitro 2006; 20 : 1202-12.

75. Monteiro-Riviere NA, Nemanich RJ, Inman AO, Wang YY, Riviere JE. Multi-walled carbon nanotubes interactions with human epidermal keratinocytes. Toxicol Lett 2005; 155: 377-84.

76. Garibaldi S, Brunelli C, Bavastrello V, Ghigliotti G, Nicolini C. Carbon nanotube biocompatibility with cardiac muscle cells. Nanotechnology 2006; 17: 391-7.

77. Flahaut E, Durrieu MC, Remy-Zolghadri M, Bareille $\mathrm{R}$, Baquey $\mathrm{C}$. Investigation of the cytotoxicity of CCVD carbon nanotubes towards human umbilical vein endothelial cells. Carbon 2006; 44: 1093-9.

78. Gabay T, Jakobs E, Ben-Jacob E, Hanein $Y$. Engineered self-organization of neural Networks 
using carbon nanotube clusters. Phys A: Stat Mech Appl 2005; 350: 611-21.

79. Rinzler AG, Liu J, Dai H, Nikolaev P, Huffman CB, Rodrıguez-Macias FJ, Boul PJ, Lu AH, Heymann D, Colbert DT, Lee RS, Fischer JE, Rao AM, Eklund PC, Smalley RE. Large-scale purification of singlewall carbon nanotubes: process, product, and characterization. Appl Phys A: Mater Sci Proc 1998; 67: 29-37.

80. Fei B, Lu H, Hu Z, Xin JH. Solubilization, purification and functionalization of carbon nanotubes using polyoxometalate. Nanotechnology 2006; 17: 1589-93.

81. Jos A, Pichardo S, Puerto $M$, Sánchez $E$, Grilo $A$, Cameán AM. Cytotoxicity of carboxylic acid functionalized single wall carbon nanotubes on the human in testinal celline Caco-2. Toxicol In Vitro 2009; 23: 1491-6.

82. Vittorio O, Raffa V, Cuschieri A. Influence of purity and surface oxidation on cytotoxicity of multiwalled carbon nanotubes with humanneuroblastomacells. Nanomed Nanotechnol.Med 2009; 5: 424-31.

83. Wepasnick KA, Smith BA, Schrote KE, Wilson HK, Diegelmann $\mathrm{SR}$, Fairbrother $\mathrm{DH}$. Surface and structural characterization of multi-walled carbon nanotubes following different oxidative treatments. Carbon 2011; 49: 24-36.

84. Zhang YB, Xu Y, Li ZG, Chen T, Lantz SM, Howard PC, Paule MG, Jr Slikker W, Watanabe F, Mustafa $\mathrm{T}$, Biris AS, Ali SF. Mechanistic toxicity evaluation of uncoated and PEGylated single-walled carbon nanotubes in neuronal PC12 cells. ACS Nano 2011; 5: 7020-33.

85. Worle-Knirsch JM, Pulskamp K, Krug HF. Oops they did it again! Carbon nanotubes hoax scientists in viability assays. Nano Lett 2006; 6: 1261-8.

\section{Yazışma Adresi}

Yrd. Doç. Dr. Perihan Oyar

Hacettepe Üniversitesi

Sağlık Hizmetleri Meslek Yüksek Okulu, Diş-Protez Teknolojisi, D-Blok, 3. Kat, 06100 Sıhhıye-Ankara / TÜRKIYYE, Fax number: +90-312-3102730, Telephone: +90-312-305 1587 / 111, e-mail: poyar73@gmail.com 